\title{
THE CATEGORIES OF TIME AND SPACE IN THE UKRAINIAN CONTEMPORARY ART AND ART RESEARCH
}

\begin{abstract}
Summary. The development of the Ukrainian contemporary visual art is surveyed by the methodological means of the theoretical aesthetics. The mechanisms of the categories of time and space are studied within the ontology plain of the creative activity. The necessity of interdisciplinary complex approach to the research of the contemporary art as a part of the social consciousness is proved and it is undertaken in the social and cultural sphere. Keywords: Ukrainian contemporary art, aesthetic experience, ontology of time and space, culture creating process.
\end{abstract}

The statement of the problem. The new radical changes and bursting turbulences in the Ukrainian cultural area and in the world community caused abrupt final of the slow consequent speculations and searches of the ways, methods and appropriate models of the national cultural and creative development. But the beginning of the notorious events in Ukrainian Maidan and following it processes have made a great impact on the global international space of the culture creative sphere of human activity. The stable social pragmatics, historical and meta historic directions of the development were ruined, social and cultural «landscape» was torn and turned into the platform for the unknown and scaring future. Social and individual context of the existence was transformed in unrecognizable manner; worldview universal clichés were shaken and seemed to be incapable for the further providing of the function to creating, preserving and transmitting culture universal achievements on the basis of versatile art forms, media channel and controversial social trends.

Therefore we are able to say that the recent experience dismantled chronological and topological dimensions of the nowadays visual art and culture. Using the metaphoric lexicon it is possible to claim that «Euclid's and non Euclid's» geometry of the contemporary art came to the collision on the $21^{\text {st }}$ century rise and none of these approaches has grasped the victory. This unsolved contradiction led to the fact that the Ukrainian contemporary visual art faced the new configuration of its temporal and spatial dimensions and as a result the problem of the artistic creativity relevant to the social consciousness had emerged. The collective consciousness sought for the individuation and individualization in the certain art objects and projects. The artists obtained the new complicated task to decode the relations between individual perception and reflections of the collective consciousness. Vincent Descombes claimed that there was only just one 
sense in which the individual exists everywhere: it was individual in the individuation process. The French philosopher points also to another sense in which the individual did not exist anywhere because the reality had never been adequate to the demand of the human autonomy that was included in the normative idea of the individuality [3, p. 97]. It is difficult to find within the frames of the individual art creative process criteria that are applicable to judge for the whole picture of the objective reality so the temporality modus estimates the relevance of contemporary artifacts to the human situation.

The ontological categories of time and space help to distinct nonsense and genuine unique ideas in the society and to draw a line between false visibility and hidden truth. The individual cognitive context of the artist subjectivity does not provide the sufficient basis for the self definition and self identification by means of art works and therefore for the realization of the free will in the cultural space. Also the artists are compelled to answer the expectations of the society to undertake the exhaustive interpretation of the reality by means of the contemporary visual art techniques. But the contemporary art is capable to meet this demand by metonymic language of images and symbols because instant fluency of the being does not provide a possibility for the fast immediate artistic conceptualization of the reality.

Requests of the social pragmatics (they should not be taken for the art marketing of contemporary art themes and trends that are not the subject of the survey) establish the indicators for the national art and the ability to articulate the key problems of the present period by the professional artistic language. A priory it is evident that the artist is always involved in the dialogue with the everyday routine events and general historical context because simultaneously he is a subject and an object of these spheres of being. It is necessary to keep in mind that the art is not a sensual and emotional analogue of the fundamental conceptual social sciences that during their history proposed the theories of the social transformations, forecasts and hypothesis of the future. In other case the researcher can be trapped by non professional illusions of the all mighty power of art and will not avoid temptation to proclaim the art as a single and general force of social development. The examples of such approaches are not so rare in Ukraine, especially recently. Led by this idea critics tend to accuse the contemporary art in loss of the actual vision, irrelevant reflection of the acute social problems, search of the easily won popularity. It is essential to assume that the ideal of the authenticity and extreme subjectivity of the aesthetic creative work «introduces the principle of the uniqueness: each of our voices has its own sense and has to articulate it. I should not adjust my life to the external conditions; I can not find the ideal beside my personality» $[9, \mathrm{p} .29]$. The above mentioned does not point to the lesser value or mistakes of the aesthetic mind but identifies its peculiarity, but not the exclusive role in the creation of the knowledge on the society as some researchers state.

The processes of individuation and individualization comprise the platform of the interaction between contemporary artistic process and social and historical development. 
Reporting previous research. It is an evident fact that the category of time was often used in the scholar researchers on art. The «time» operator is a formal theoretical instrument which is the key tool of the scientists - authors of the numerous and from the pathos of the objective single truth. The chronograph method of the history of art is led by metaphysical equity of the historical time and space historic surveys on the Ukrainian art, comparative descriptions, the time losses its forward direction and linear characteristics and in such a way the time category turns into the practical indicator that saves art science from excessive subjectivity and no doubt that it is an advantage of the academic researches on art. We should mark fundamental scholar papers by researchers of the National Academy of art of Ukraine and Modern Art Research Institute which have not chosen well known path of simple descriptions and subjective interpretations, with which readers' audience often associate sciences on art. The scholars of the above mentioned institutions developed scientific conceptions in the art researches: it means to express by means of notions and categories the imaginative and symbolic nature of art in connection with the social and cultural space taken in its temporal content. Academic researches in the theory and history of art make a distinction between individual subjectivity of the aesthetic experience and objective laws of creation and perception of the contemporary art, necessary and sufficient social and economic prerequisites for its free creative existence. Within the frames of this article we should mention important works by Zubavina I., Rohotchenko O., Moussienko N. and others who while investigating new object define new contemporary sense of cultural universalities, notions and categories of art theory.

The fundamental survey by V. Sydorenko is an example when internal and external observer is at the same time an active participant of the art processes in Ukraine. The analyses of the contemporary Ukrainian art given in this book unveils the cultural development which could be smooth and continuant and sometimes dotted and stopping at the stagnation period; the author shows how the creative motivation leads to the cognitive and social legitimating of the newest art practices on the national ground.

The philosopher O. Bosenko works in the sphere of the transcendental aesthetics and uncovers codes of eliminating classic fundamentals of the art in the metaphysics of contemporary being. In his researches the attention is attracted to the fact that the historical category of time losses its flagman status in the becoming of the modern culture and accidental happenings comprise the chronologic modus of the cultural reality: «Every thing which the temporality touches becomes accidental and random as well as time itself where art and philosophy forms are represented and loss the formality thus they turn into the pure transformation» [2, p. 196]. The classical aesthetic tradition stated that temporal modality of art is a way of reconciliation between art, consciousness and reality; as a researcher claims now in his numerous publications today temporality category in art is a disturbing trigger that creates gaps intricate traps for the acting subject 
of the contemporary art. Therefore analytical results of classical aesthetics are not appropriate for evaluating contemporary art. But we could not name «the negative countdown of the time» this process in the modern culture (as analogue of Theodor Adorno negative dialectics), it is possible to define the time operator of the contemporary art as «a zero potential», the initial ground for further development.

The goal of the study. The research is aimed at unveiling all the complex laws, regularities of the interaction of time and space categories of the contemporary art taken in their symbolic and perverted forms.

The main content. The today's art gave up the attempts to find the basis inside itself or in external reality; the time category serves now as a two-side mirror. The time taken as a philosophic category and the instrument of the aesthetic cognition does not help the contemporary art to obtain unified reality picture out of multi dimensional world and construct a foundation for the aesthetic activity. The temporality of the contemporary art is an instrument of the aesthetic cognition and far from the categories «true» and «false» which always were vague even in classical aesthetical thought. The «time» dimension is often eliminated from the ethical side of the artistic subjective activity presented by moments of choice, conception ideas and unfortunately art process losses part of its inner moving force. The artists often play dangerous games with reality and chase the freedom in efforts to provoke and bring to surface the intangible time and make it relevant to the artistic images and symbols. But it should be noted that such aesthetic games and flirting with tough reality make the art defenseless and a toy for the dilettantes, spreading banal myths «a beauty will save the world». Thus we came to the assumption that it is hard to create art «in front of the light» especially when this light is disappeared historical time. At the same time such conclusion is not pessimistic if we cease to find the balance between metaphysics of time and space and creative acting of the artists their relations transform into the tense controversial moving process of the communication inside cultural and social space. As the phenomenological and partly hermeneutical theories of contemporary art claim that art experience and aesthetic activity are emerging symbolic and imaginative structures for the exchange of senses and ideas which demand their spatial and temporal verification. The possibility of the emergence and replication of these communicative structures embodied in art works proves the thought that the aesthetic judgments are no more in direct dependence relations with the time and space as metaphysics categories. Subjective effects and the results of the communicative structure functioning comprise the basis of the contemporary art development and culture as well.

By its nature and origin the art as a form of the social consciousness and a way of the individual cognition and perception can not be absolutely transparent for the analysis it is a possibility of being itself, the ground of the first and final acquisition of the reality by human consciousness. 
While investigating the contemporary art as a social phenomenon we distinct some characteristics pointing to the necessity of the «time» category that expands heuristicperspectives for the art researchers. This standpoint does not reduce the achievements of the transcendental aesthetics in uncovering the specifics of the contemporary art; it is a choice of the research method. From the view of the pragmatics (in other words the sociology of art) the area of aesthetic scholar surveys should engage the becoming of the artistic world that embraces the art objects, their creators, social and economic conditions exactly measured and linked to the certain historical period for the more or less successful art development. Time inputs sense and value into the art field, art sphere reaches it relative autonomy and sometimes shadowed by illusion of its exclusive art aesthetic experience. At the certain moment the correlation and consequent interaction between art space and social, historic and economic situation happens and it leads to the emergence of the new art institutions and recognition of the innovative art practices. According to the statement of the well known French sociologist Pierre Bourdieu [10], the dilemma of opposition between aesthetics as a science on the essence, form and perception of the art and the theory reducing the entire unique art world to the social context is solved. So the investigation how the social time becomes subjective and individual in contemporary art sphere becomes a starting point in the survey of the above mentioned problem on subjectivity and objectivity of art.

At the beginning of the third millennium it seemed that all the catastrophes and radical social changes are left in the past. Most of the representatives of the humanitarian sciences unilaterally agreed that the peak of spiritual tension and radical turn in all spheres of human activity was reached during the World War II and in after war period. Also the fall of the Soviet totalitarian system could not be underestimated in restructuring the hierarchy of the human values in all aspects of life. The new world order stimulated the birth of the new type of social cultural life and art practices and ideals. There was a widespread hope that the previous human achievements would comprise a solid foundation for constituting the new type of national identity (the Ukrainian national identity as well) in the pluralistic cultural space of the globalized post industrial world. Modern human space was already characterized as informational where linear connections gave place to the grandiose network of the symbolic and semiotic social and cultural inter exchange and communication. Thus some Ukrainian and foreign scholars obtained a pretext to propose the ideas of the annihilation of history and disappearance of the cultural development in the classical and traditional sense. So the Ukrainian contemporary art and researches on it became a fruitful ground for implementation and development of the various Postmodernist theories, but it should be noted that this direction of the social and cultural thought came to Ukraine much more later the time they were considered the revolution breakthrough. 
Postmodernist theory emerged during students' protests in France back in 1968, in reality and circumstances which differed a lot from the situation of the beginning of the $21^{\text {st }}$ century in Ukrainian cultural and art space. In 1970-1990s the leftist movement was regarded as very progressive. Postmodernist impressive ideas on the hyper real allusions that were not any more rooted either in time or in space attracted the European intellectual elite by their opposition to the bourgeois worldview and found their implementation in the cultural practices. Later it became obvious that negativist speculations and ambiguous implications of Postmodernism in cultural practices did not provide heuristic potential and lead to the vicious circle of the negating the ability of culture to meet the changes and adjust to them functionally and substantially in the concrete specific national form.

We should pay necessary respect and tribute to the founders of the Postmodernist discourse which accomplished an important task of creating the ground for the breakthrough into the reign of the spiritual and artistic freedom. But it is worth to note that much earlier than Postmodernist approach had become popular in the Ukrainian cultural space it demonstrated some visible limitations insisting on the disappearance of the ontological spatial and temporal foundations of the culture creating process in the informational society. It is plausible to agree with such conclusion just in one point: evidently the cultural process aimed at the simple replication and preservation of the traditions is compelled to stagnation in attempts of reanimating archaic social and cultural values. The lust to life and form creating function of culture and art consist in encouraging innovations and inventions that enrich the aesthetic experience as a part of the social consciousness. Nevertheless the Postmodernist ideas were met with neophyte enthusiasm by Ukrainian artists and researches and prompted intellectuals for artistic and scholarly work in the late 1990 s and even in the $1^{\text {st }}$ decade of the $21^{\text {st }}$ century. Though the dynamics of the social movement went ahead the speculations of the intellectual artistic elite and events of the 2013-2014 years in Ukraine and following then cardinal changes in the social situation raised questions on the moral obligations of the artists and the aesthetic categories of time and space as an essence of the social transformations and turbulences in Ukraine. In this context we may propose the statement by the American philosopher John Dewey; who investigated the levels of freedom in society and its impact on the cultural progress, stressed that people fight for acute for them values, but for the formation of the society in creative sense from a group of people there should be a unity of values, without it any social group, class nation are in danger of «molecular collapse» having just mechanical contacts with each other. [4, p. 42] So, Postmodernist applications in art research demonstrated their weakness and certain borders for further progress. Especially in the recent period there were obtained convincing proofs that Ukrainian art movement in a lot of its implications have not lost the substantiality of time and space ontological criteria. After receiving reincarnation on the Ukrainian cultural ground postmodernist trend lost its pathos here. 
The Ukrainian contemporary visual art does not limit proclaim self sufficient way of development and proves by its achievements and varieties of directions (conceptual, non figurative and others trends) that articulate in their specific ways the artistic vision of contemporary aesthetic activity. Despite essential formal differences today all the directions of the contemporary art operate and interact with each other and objective reality in «existential space» which E. Levinas named «between us» identifying in this multilateral communication intersubjective character of the contemporary social and cultural field. The paradox and intrigue of the art as a social phenomenon (not only Ukrainian) consists in controversy between inner implications and claims and the results of the creative activity unfolding in the certain social space and historic time.

For better comprehension and profound analyses we propose to engage such theoretical social and historical concept as event. The event serves to be the unit of the social measurement of the cultural and social development in the era of the informational society. The event is a minute form of social motion. The art and cultural event is unveiled as a reactive form which reflects the reality in the light of the subjective vision of the artist. The event contains the artistic symbolic narrative provoked by reality aftermath this «miraculous crystal» of conscience perishes in the chaos of being and confirms the unreality of time category for the artistic aesthetic conscience. Therefore we see the basic roots of the anguish by audience and critics of the contemporary art for the lost substance of time and space categories and searches of the new ontological foundations for the aesthetic activity.

The symbolic allusions are widely used in the contemporary Ukrainian conceptual art. Earlier in the 1960-1970s they contained hidden potential to resist the totalitarian repressive regime against Ukrainian genuine culture, in the postindustrial society conceptual art allusions are aimed at generating innovative ways of the artistic and aesthetic activity producing the cultural capital in terms of the sociology. The role of the art in the creation of the cultural capital of the society (in the Ukrainian context) could not be overestimated, the conceptualist direction in Ukraine combines in the works utopian, anti utopian, traditionalist, sacral ideas, avant-garde influences, in other words we witness intercrossing and interpenetration of temporal and spatial markers of the cultural process.

As it already had been mentioned the year of 2013 put an end to the unhurried slow dialogue on the features, vectors and perspectives of the cultural future between all engaged in art process and civil society as a whole. The Ukrainian intellectual community (the artists and researchers as well) faced a task to comprehend on the notional and categorical level the future cultural and historical fate of Ukraine. Without fear and vain hopes the intellectuals recognized that shift of axis in history was happening which meant the radical transformations of main markers of the European cultural process. But this process has much more optimistic implications and outcomes then O. Spengler wrote in quite another situation in his «The Decline of the West». The so called decline 
could be avoided by taking into the account emerging of the new cultural values and elaborating innovative artistic forms with the aim to integrate into the European cultural field and preserve unique Ukrainian cultural and art achievements as an essential contribution into the world cultural treasury. The metaphor «axis of history» does not mean anymore the fall of humanistic values as in the initial source, now it can be compared to the «point of the bifurcation» in synergetic theory when the time and space compress in one point and moment then they burst out thus giving birth to the billion of chances and enlighten the new fascinating perspectives of the future development. Art events in Ukraine confirm convincingly this idea.

The practical artistic manifestations and attempts to grasp the ontology of time and space in aesthetic activity could not be surveyed without reference to the phenomenology of art as a branch of aesthetic philosophy. The phenomenological theory defines the categories of time, space and their explication - temporality as the basic characteristics and at the same time as a main instrument of the aesthetic experience: «The experience of consciousness is not comprised of discrete acts; it is a complicated continual flow of feelings which is analyzed by adding the category of temporality» [5, p. 33]. The aesthetic sensual and practical experience of constituting art object depends on the turned inside subjective continuity of the individual consciousness. In the present research the content of the above mentioned categories is not limited by pure theoretical speculations it is possible to prove that these it can be expand to the explanation of the core laws and regularities of the contemporary aesthetic practices. The temporal dimension contains also historical time as a creative moving force of the cultural process. Time and space intertwining of the artistic explication of the world also involve all social and economic conditions and prerequisites for the art consequent development. Therefore temporality dictates the relations between subject and object taken in their continuity. Besides having above mentioned functions the categories of time, space and temporality serve as a methods of content analysis of art dialogue with social utopias and future projections, depiction of the present real being and myths about it, and explanation of the monologue of the past traumas. So the widening of the time and space notions helps to enlighten and unveil unknown till now specifics of the contemporary artistic process in Ukraine as an object scholar conceptual studies and the subject of the theoretical research.

Within the context of this research it is reasonable to review art progress in Ukraine for the last few years because as it already had been mentioned the events of Maidan and following them were a trigger which prompted to appear on the surface those hidden but essential features and concepts of art that were hidden before. The new chronograph of the art hypostases on the Ukrainian scene may start with the presentation in August of 2014 «The Fatherland» exhibition within the frames «The Ukrainian Landscape: on another side of despair» project. The idea of this exhibition was far from complicated paraphrases and intricate metaphors, reminiscences, citations of classics 
or popular slogans. Pure conscious challenge of this exhibition was to unite cultural efforts to save Ukraine as an independent country. The three parts of this exhibition «The Fatherland: Real», «The Fatherland: Today», «The Fatherland: Future» are the symbolic narration and search for the constants and roots of the national culture in temporal symbolic canvas of the Ukrainian cultural canvas. The past is not explicit and it is dismissed consciously or deliberately. Unfortunately sometime the historic past becomes the object of pseudo scholastic speculations of art critics when a lot of psychoanalysis terms such as unconscious, subconscious, suggestion et cetera are loosely applied having nothing in common with the scientific approach. If to analyze the aesthetic experience aimed at uncovering historic past, we may assume that the past experience acquired the alienated presentation in art forms of utopian symbols, anti utopian manifestations, myths of the victim fate of the nation. Invisibly the past is present in signs and symbolic constellations of the Ukrainian contemporary art. The main complication which the artistic actions face dealing with the past chimaeras is that alienated forms of it endanger real authentic present and future of culture.

But when we are very close to unveiling the truth of art it is more difficult to leave past stamps and clichés. Irreversibility of time gives the ground for the alienation of past and creation of the subjective aesthetic images of the past epochs by moving history on the art canvas. Absence of the real object is compensated by the symbolic text of the artistic images. When the history is fixed by the art instrument the perception of art objects is blurred by false obviousness of symbols - the aesthetic consciousness undertakes an attempt to look in itself from outside.

The phenomenological theory propose to solve the paradox of the contemporary aesthetic perception in such a way: «it is necessary to get the signs and symbols free from their denotations and only in this case they will acquires all the links with other symbols» $[7, \mathrm{p} .33]$. In accordance with this logic the real authentic essential ideas of the contemporary art depend on the interpretations of the past stigmas and coming to conclusion that they lost their influence on the present and future. Since the presentation of above mentioned project passed three years and we witnessed how artistic creative activity in Ukraine went ahead on the path of introducing the temporal dimension of the aesthetic conscience and experience into the social and political life of the country. The contemporary Ukrainian art refused to revive the historical past and tried to avoid its justification by artistic means. Input of the lost in the past historical symbols took place in a more complicated and intricate way. In a lot of art projects Ukrainian conceptualists stress on the absolute self sufficiency of the present times. Shifting of time notion of temporal intentions of creative aesthetic consciousness demonstrates the desire to start the construction of the new cultural history that does not mean its «rewriting» under the influence of political situation as it often happened in the previous historical periods in Ukraine. The challenge of it means the recognition of contemporality 
as the starting point for constituting the new type of the Ukrainian national identity. The potential of the Ukrainian contemporary art is enriched with the euphoria and at the same time skepticism and even sarcasm (as it often could be observed in the art works by O. Roitburd), all these features give the variety of chances and add acceleration to the temporal vectors of art process. This is not a new insight in apprehension of the becoming and unfolding of the social history and in attempts to give an answer on sense or senselessness of the human being. A decades ago the American thinker F. Fukuyama proposed thesis of the «end of the history», meaning that the previous historical evolution exhausted its resources and there is a need to seek for the new social and cultural moving forces of the civilization process. The turning points in human history are not only the subject of the thorough survey by humanitarian sciences they are explained by the everyday common consciousness, collective justification of social changes and of course aesthetic activity depicts them in the results of the artistic perception of the world. The aesthetic creative activity reveals the historical temporal characteristics due to the modus of time and space inbuilt in the artistic personal vision of the reality. The contemporary art exists and reproduces its evaluation of the objective reality in intricate subjective form of individual temporal and spatial paradigms. But as it already has been said personal emotional and sensual context of art works deprives world from its pathetic manifestation using irony and sarcasm. The artistic comprehension of contemporary being is often compared with a game of symbolic senses: «Although this game of de contextualization and recontextualization bears a certain part of irony that deserves our attention having in mind the perspective of the privatization of the past ... Indeed the human memory is based on the contextualization within the frames of the constantly changing associative lists $\gg[1, \mathrm{p} .263]$.

Fragility and vulnerable sensitivity of the artist could be seen through cynic pose mask of the contemporary art tricks. The existential anxiety about the human future is conceived in the art process and explicated through the prism of the past and present. Human existence in the certain rapidly changing temporal dimension seeks for the space unshakable ground. In the contemporary Ukrainian art landscape theme serves as a axiology carcass providing a space for grounding and substance basis for the fluent temporal images and senses. It seems weird but in contemporary Ukrainian painting the landscape is not a pastoral classic art but a ground where entity of time and space categories unveil their hidden immanent features. This phenomenon is proved by a lot of works by well known Ukrainian painters: O. Tistol, A. Kryvolap, V. Sydorenko ( $\ll$ The Beach and the Coast» project, Kyiv, 2017) and others. The landscape of Ukrainian artists propose the solution to the eternal apory of aesthetic activity and perception in which past, present and future could contradict each other maintaining connection only in ideas of artists consciousness. The variety of landscape transformation in the contemporary art is a place where uncatchable time and space peacefully reconcile. Entity of the place 
a time as a initial ground for the beginning of the subjective aesthetic work of consciousness. It is necessary to note that the review and analyses of the recent artistic practices in Ukraine would be insufficient without mentioning the photography and its convergence with the other types and genres of the contemporary art. Prominent Ukrainian photographer Borys Mykhailov reached in his artifacts the ultimate concentration of temporal and spatial individual characteristics of the reality. Temporality as a phenomenological category did not lose its dynamics but temporal and spatial lines of the human life were featured on his photos in a statistic moment between the spins of the action.

The discourse on the temporal and spatial intertwining in the Ukrainian national art and culture and their transformations would be impossible without actualization of the historical memory. For the last few years the intellectual community in Ukraine had initiated a campaign on reevaluating the role and significance of key personalities and events of the national culture thus enabling the essential achievements of past to be resurrected in present and future. The goal of it was to uncover new hypostases of the national cultural heritage acquiring another essential characteristics and perspectives for development in the contemporary environment. The celebration of $200^{\text {th }}$ anniversary of Taras Shevchenko birthday turned into the outstanding event in the artistic, cultural and social life in Ukraine. Despite the fears of the formal and official approach the celebration prompted an overwhelming response in the cultural sphere. The general accent was made on the unity of the will, freedom and national symbolic roots in the treasury of Kobzar's heritage and their embodiments in the today's art practices. The Ukrainian artists exposed their vision of the legendary Kobzar on a lot of stages, the society reached the new level of understanding and applying the ideas of Taras Shevchenko, by operating with the proper time and space aesthetic means of contemporary artistic conceptions. The art and social science researchers contemplated on the significant directions that sprang after recursive return of Taras Shevchenko in the $21^{\text {st }}$ century. The life and creative works by Taras Shevchenko are active symbol and fundamental moving force of national progressive development: «The longer is the distance, the faster is the return to present reality» $[7, \mathrm{p} .35]$.

In 2015 the Ukrainian and world artistic community were given the opportunity to contemplate about an era of avant-garde and its history through the century as a hundred years ago K. Malevich revealed to the public in Kyiv his «Black Square» that opened a new world for the artistic advance process. Through the history of Ukrainian avant-garde and such its direction as neo avant-garde we see as exclusively subjective content of artistic creative vision turned into the temporal and spatial artistic process that started to develop according its independent laws. The essential and vital force of time and space concepts of avant-garde and neo avant-garde in all their fanciful shapes and deviations, is still an unexplored field for the special art research and humanitarian sciences in general. 
Conclusions and perspectives of research. Coming to conclusions of investigating the essential features of time and space categories of the Ukrainian contemporary art and their applications in the art research it is possible to state that immanent intrinsic content of temporal and spatial art features determine the laws and regularities of the modern art process. The entity of them is exposed in aesthetic individual experience that by fact of its endurance into the social consciousness acquires great importance for the culture creating process in Ukraine as a part of the world cultural dynamic transformations. The capacity and heuristic potential of the contemporary art (especially its conceptualist branch in Ukraine) is revealed due to the ontological transitive activity of time and space markers in the certain historical periods of the social life. The concepts of contemporary art taken in their time and space dimensions concentrate content, sense and nature of the imaginative symbolic artistic narrations and dictate their perception and apprehension on the social level. The unity of time and space is a dynamic modus necessary for the existence of the contemporary art as a ground of the aesthetic experience. The Ukrainian contemporary art gradually steps on the new level of its development, taking active role in the social processes.

The ontological categories of time and space and their dynamic connection named as temporality determine the objective results of the art practices which significantly differ from the subjective intentions of the artists. The aesthetic experience is viewed as an interactive activity of the artist and the audience. This experience undergoes many stages of unfolding the essence of the created art objects: from individual subjective passive perception to the incorporating artistic experience into the social consciousness and social practices.

\section{References}

1. Ankersmit F. Postmodernist.s'ka «pryvatyzatsiya» mynuloho [Ankersmith F. Postmodernist Privatization of the Past] // Ukrayina moderna [Modern Ukraine]. 2009. \# 4 (15): Pam»yat' yak pole zmahan' [No. 4 (15): Mamory as a battlefield]. S. 246-272.

2. Bosenko A. V. Sluchaynaya svoboda iskusstva [Bosenko A. The Random Freedom of Art]. Kiev: Himdzhest, 2009. $584 \mathrm{~s}$.

3. Dekomb V. Indyviduatsiya ta indyvidualizatsiya [Descombes V. Individuation and Individualization] // Filosofs'ka dumka [Philosophic thought]. 2006. \# 1. S. 82-109.

4. D'yuyi Dzh. Svoboda i kul'tura. Problema svobody [Dewey J. Freedom and Culture. The Problem of Freedom] // Zarubizhna filosofiya XX stolittya: U 6 kn. [Foreign philosophy of the $20^{\text {th }}$ century: In 6 volumes]. Kyyiv, 1993. Kn. 6. S. 38-45.

5. Kebuladze V.I. Fenomenolohiya dosvidu [Kebuladze V. The Phenomenology of Experience]. Kyyiv: Dukh i Litera, 2011.280 s.

6. Musiyenko N.B. Mystetstvo Maydanu [Moussienko N.B. The Art of Maidan] / IPSM NAM Ukrayiny. Kyyiv: Mayster-prynt, 2015.96 s.

7. Riker P. Estetychnyy dosvid [Ricœur P. The Aesthetic Experience] // Dukh i Litera [Spirit and Letter]. 2006. \# 15-16. S. 30-46. 
8. Sydorenko V.D. Vizual'ne mystetstvo vid avanhardnykh zrushen' do novitnikh spryamuvan': Rozvytok vizual'noho mystetstva Ukrayiny XX-XXI stolit' [Visual art: From avant-garde changes up to the newest trends] / IPSM AMU. Kyyiv: VKh[studio], 2008. 188 s.

9. Teylor Ch. Etyka avtentychnosti [Taylor Ch. The Ethics of Authenticity]. Kyyiv, 2002. $128 \mathrm{s.}$

10. Bourdieu P. Genese historique d'une esthetique pure // Les cahiers du Musee national d'art moderne. Printemps. 1989. № 27. P. 5-12.

\section{Мітература}

1. Анкерсміт Ф. Постмодерністська «приватизація» минулого // Україна модерна. 2009. № 4 (15): Пам’ять як поле змагань. С. 246-272.

2. Босенко А. В. Случайная свобода искусства. Киев: ХимАжест, 2009. 584 с.

3. Аекомб В. Індивідуація та індивідуалізація // Філософська Аумка. 2006. № 1. С. 82-109.

4. Аьюї Аж. Свобода і культура. Проблема свободи // Зарубіжна філософія ХХ століття: У 6 кн. Київ, 1993. Кн. 6. С. 38-45.

5. Кебуладзе В. I. Феноменологія досвіду. Київ: Аух і Аітера, 2011. 280 с.

6. Мусієнко Н.Б. Мистецтво Майдану / ІПСМ НАМ України. Київ: Майстер-принт, 2015.96 с.

7. Рікер П. Естетичний досвіА // Аух і Аітера. 2006. № 15-16. С. 30-46.

8. Сидоренко В.А. Візуальне мистецтво віА авангардних зрушень до новітніх спрямувань: Розвиток візуального мистецтва України XX-XXI століть. Київ, 2008. 188 с.

9. Тейлор Ч. Етика автентичності. Київ, 2002. 128 с.

10. Bourdieu P. Genese historique d'une esthetique pure // Les cahiers du Musee national d'art moderne. Printemps. 1989. № 27. P. 5-12.

\section{Олена Станіславівна Аккаш}

Категорії часу та простору в сучасному українському мистецтві та мистецтвознавстві

Анотація. Розглянуто розвиток сучасного українського візуального мистецтва із застосуванням метоАології теоретичної естетики. АосліАжено механізми функціонування категорій часу та простору в онтологічній площині творчої Аіяльності. Обгрунтовано необхіАність міжАисциплінарного комплексного піАходу до вивчення сучасного вітчизняного мистецтва як скмадової розвитку суспільної свідомості у соціокультурному полі.

Ключові слова: українське сучасне мистецтво, естетичний досвіА, онтологія часу та простору, культуротворчий процес.

\section{Елена Станиславовна Аккаш}

Категории времени и пространства в современном украинском искусстве и искусствоведении

Аннотация. Рассмотрено развитие современного украинского визуального искусства с использованием методологии теоретической эстетики. Исследуются механизмы функционирования категорий пространства и времени в онтологическом поле творческой деятельности. Обосновывается необходимость межАисциплинарного комплексного подхода к изучению современного визуаньного искусства как составляющей части развития общественного сознания в социокультурном поле.

Ключевые слова: украинское современное искусство, эстетический опыт, онтология времени и пространства, культуротворческий процесс. 